Piotr Sygut ${ }^{1}$, Dorota Klimecka-Tatar ${ }^{2}$

\title{
ABC TECHNOLOGY USE TO EVALUATE THE PRODUCTION OF POLYSTYRENE MACHINE
}

\begin{abstract}
The paper presents the results of research carried out in one of the national companies engaged in the production of thermal insulation materials used in construction. There have been characteristics of the machines taking in the production of polystyrene and rated it using the $\mathrm{ABC}$ technology method and a five-point Parker scale.
\end{abstract}

Key words: polystyrene production, $\mathrm{ABC}$ technology, Parker scale

\section{Characteristics of machinery and equipment used in the} enterprise

\section{Machine for frothing of polystyrene with dryer}

Polistyrene (HYLA I., 2000., OSIECKA E., 2005., BORKOWSKI S., UlewiCz R., SElEJdAK J., 2005, CisZEWSKi A., RAdOMSKI T., SZUMER A., 1998) given automatically by means of a screw feeder under the influence of steam and mixed vigorously with it, increases its volume several times. The control is done via the touch screen, thanks to the insertion of glass can visually control the process. Upon receipt of the anticipated outcome of the foamed granules are dried with hot air.

Machine installed power and performance:

- $380 \mathrm{~V}$,

- $20,5 \mathrm{~kW}$,

- efficiency to $100 \mathrm{~m}^{3} / \mathrm{h}$ (at a density $15 \mathrm{~kg} / \mathrm{m}^{3}$ ).

The demand for steam:

1 Dr inż., Czestochowa University of Technology, Faculty of Management, Institute of Production Engineering, e - mail: piotr.sygut.wz@gmail.com

2 Dr inż., Czestochowa University of Technology, Faculty of Management, Institute of Production Engineering, klimt@wip.pcz.pl 
- $\mathrm{p}=0,5 \mathrm{MPa}$ - use $5 \mathrm{~kg} / \mathrm{m}^{3}$.

The demand for compressed air:

- $\mathrm{p}=\min 0,6 \mathrm{MPa}-35 \mathrm{l} / \mathrm{min}$.

Machine for frothing of polystyrene with dryer were shown on fig. 1.

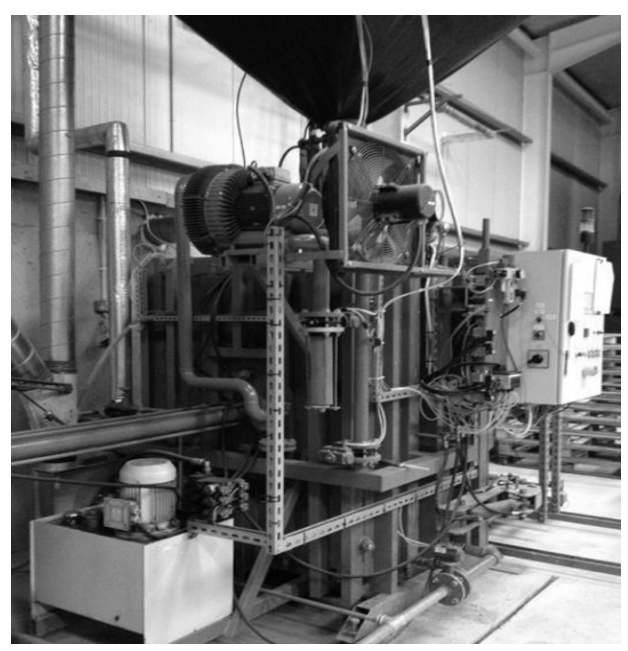

Fig. 1. Machine for frothing of polystyrene with dryer.

Source: Own interpretation

The machine for forming blocks of polystyrene

The machine for forming blocks of polystyrene (Fig. 2). Due to its automation, machine controls all functions, such as:

- opening and closing the chamber,

- temperature maintenance,

- dispensing cooling water,

- dispensing of polystyrene,

- dispensing of steam,

- cooling and moisture extraction.

In the mold block is formed of expanded polystyrene beads held together. Vacuum device removes from the chamber an excess of steam. 
The machine prepares ready polystyrene block with dimensions of $4080 \mathrm{x}$ $1250 \times 1050 \mathrm{~mm}$, which after seasoning is ready to cut on polystyrene plates.

Machine installed power and performance:

- $380 \mathrm{~V}$,

- $37 \mathrm{~kW}$,

- efficiency to $100 \mathrm{~m}^{3} / \mathrm{h}$ (at a density $15 \mathrm{~kg} / \mathrm{m}^{3}$ ).

The demand for steam:

- $\mathrm{p}=0,6 \mathrm{MPa}$ - zużycie $32-52 \mathrm{~kg}$ pary na $1 \mathrm{cykl}$.

The demand for compressed air:

- $\mathrm{p}=\min 0,6 \mathrm{MPa}-80 \mathrm{l} / \mathrm{min}$

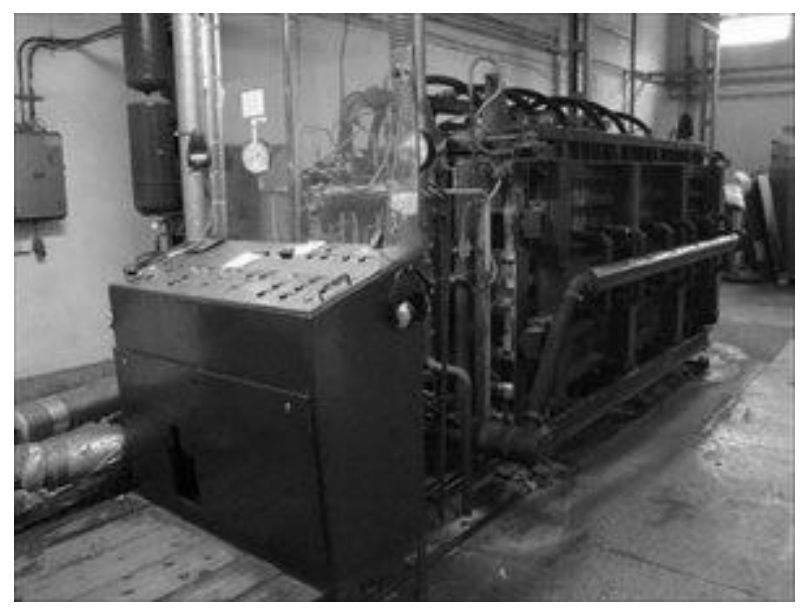

Fig. 2. The machine for forming blocks of polystyrene.

Source: Own interpretation

The line to cut polystyrene (vertical, horizontal and lateral)

Automatic device used for cutting blocks of polystyrene on board (Fig. 3). Due to a system of sensors connected to a computer line requires a minimum contribution of human labor. Cutting block is done using copper-clad wire having a $0.4 \mathrm{~mm}$ in diameter, in three planes:

- vertical, 
- horizontal,

- the transverse.

Styrofoam plate thickness is regulated and begins at $10 \mathrm{~mm}$. The blocks are loaded automatically on line. Waste which are formed when cutting the blocks return into production.

Machine installed power and performance:

- $380 \mathrm{~V}$,

- $36 \mathrm{k} \mathrm{W}$,

- efficiency to $100 \mathrm{~m}^{3} / \mathrm{h}$ (with a plate thickness of $50 \mathrm{~mm}$ and a density of $15 \mathrm{~kg} / \mathrm{m}^{3}$ ).

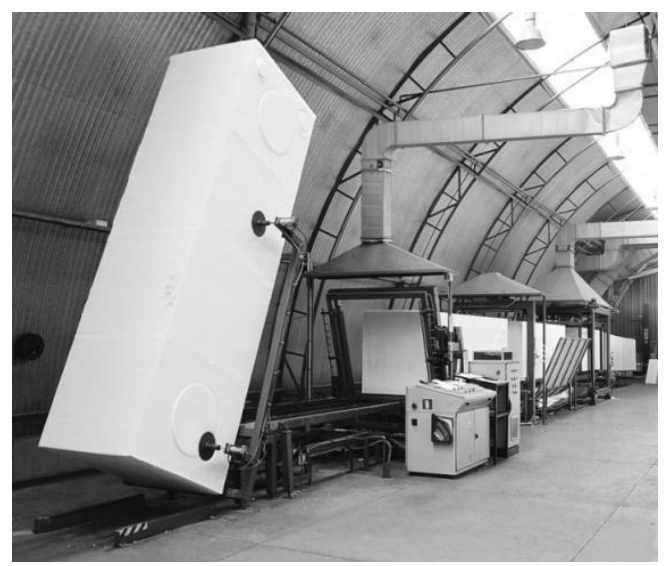

Fig. 3. The line to cut polystyrene.

Source: Own interpretation

The plates packaging machine with feeder

Packing styrofoam plates, carried out automatically using the feeder plates (Fig. 4). The plates are wrapped in foil with a thickness of 0.025 to $0.03 \mathrm{~mm}$ which is then heat sealed. Styrofoam prebuilt packages are stored in the warehouse.

Machine installed power and performance:

- $380 \mathrm{~V}$, 
- $5,7 \mathrm{~kW}$,

- 3 - 5 packeges/min.

The demand for compressed air:

- $\mathrm{p}=\min 0.6 \mathrm{MPa}-130 \mathrm{l} / \mathrm{min}$.

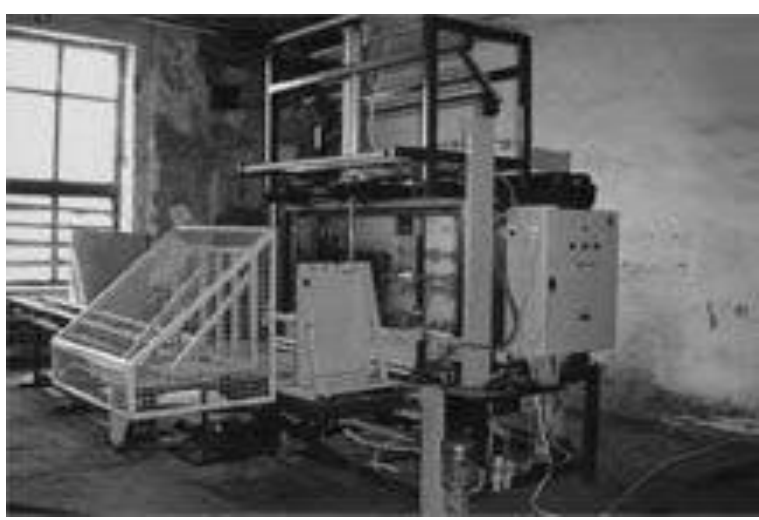

Fig. 4. The plates packaging machine with feeder.

Source: Own interpretation

\section{Machines evaluation of modernity using the $A B C$ technology method}

$\mathrm{ABC}$ technology method is used to assess the level of of modernity parts of machines and devices, their values and suitability for development time analysis. The method consists in dividing the components of machines and equipment according to their importance. These parts are divided into three groups: A, B and C, as the name suggests analysis. In group $\mathrm{A}$ are the main components that determine the outcome of the production process. Group B refers to components that indirectly affect the process, but they must not be underestimated. Group $\mathrm{C}$ is a part of that in a small way affect the operation of the machines. All components are assessed in a five-point Parker scale (BORKOWSKI S., 
2004). Levels of this scale are as follows (BORKOWSKI S., SELEJDAK J., SALAMON S., 2006, SELEJDAK J., BORKOWSKI S., 2006):

- level 1 - simple parts can be produced using craft techniques;

- level 2 - components that were generated by unaltered and known technology for many years;

- level 3 - parts of which were produced using a technology that requires appropriate technical knowledge;

- level 4 - parts manufactured using modern technology;

- level 5 - parts of which were manufactured according to the latest technologies that have been patented and are known only to a particular company.

$\mathrm{ABC}$ method technology has been applied to the assessment of modern machines and devices using a five scale Parker. The results were presented in tables and graphs for the three most important machines involved in the production process of expanded polystyrene (the machine for forming blocks of polystyrene, the line to cut polystyrene and the plates packaging machine with feeder). In Table 9.1 and Fig. 9.5 presents data on the assessment of modernity for the machine for forming blocks of polystyrene according to the $\mathrm{ABC}$ method of technology and Parker's five-point scale.

From the data presented in Table 1 and Fig. 5 can be seen that none of the components has not been assessed at 5, so the company does not have parts that have been manufactured using the most modern technologies are specific to the company. The control system (A1), console (A2) and an electric motor (A4). Only auger (A3) has been set at 3. 
Table 1. The technology level of parts the machine for forming blocks of polystyrene

\begin{tabular}{|l|l|l|l|}
\hline $\begin{array}{l}\text { Group units of the } \\
\text { machine }\end{array}$ & No. & Sub-assembly machine & Technology level \\
\hline A & A1 & The control system & 4 \\
\cline { 2 - 4 } & A2 & Console & 4 \\
\cline { 2 - 4 } & A3 & Screw feeder & 3 \\
\cline { 2 - 4 } & A4 & Electric engine & 4 \\
\hline \multirow{4}{*}{ B } & B1 & Frequency inverter & 3 \\
\cline { 2 - 4 } & B2 & Gear drive & 3 \\
\cline { 2 - 4 } & B3 & Dryer & 3 \\
\cline { 2 - 4 } & B4 & Mucus injector & 4 \\
\hline C & C1 & Construction of machines & 2 \\
\cline { 2 - 4 } & C2 & Housing & 2 \\
\hline
\end{tabular}

Source: Own interpretation

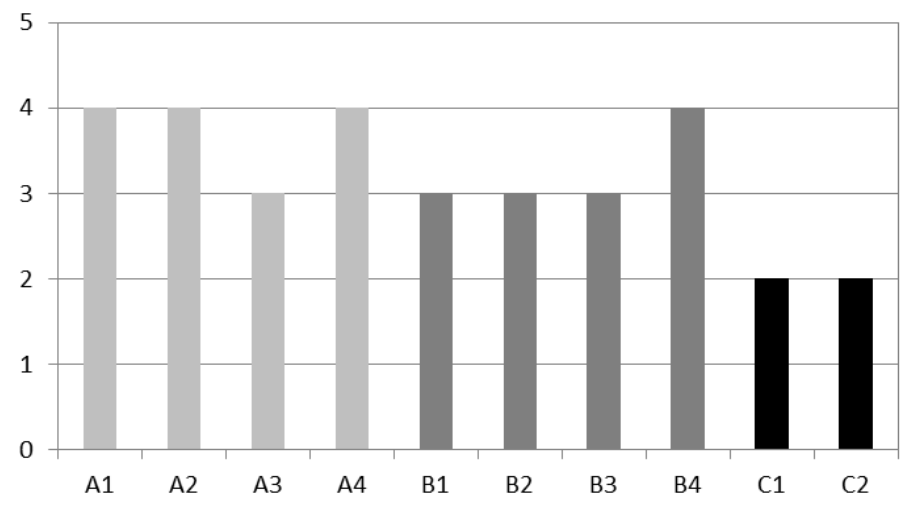

Fig. 5. The chart of technology level of parts the machine for forming blocks of polystyrene

Source: Own interpretation 
The base part of group A is $75 \%$ assemblies rated at level 4, which were prepared by using modern technology and they are: the control system, console, electric engine.

Components assist with group $\mathrm{B}$ rated at level 3 are: the frequency inverter (B1), gear drive (B1) and dryer (B3). Injector mucus (B4) is the only one was rated at level 4.

Parts of collateral, which belong to group $\mathrm{C}$, namely the construction of the machine (C1) and housing (C2) have been qualified to level 2 .

Table 2 and Fig. 6 presents an assessment of modernity of machine to cut polystyrene according to the ABC method of technology and Parker's five-point scale.

Table 1. The technology level of parts the machine to cut polystyrene

\begin{tabular}{|l|l|l|l|}
\hline $\begin{array}{l}\text { Group units of } \\
\text { the machine }\end{array}$ & No. & Sub-assembly machine & $\begin{array}{l}\text { Technology } \\
\text { level }\end{array}$ \\
\hline A & A1 & Electric engine & 4 \\
\cline { 2 - 4 } & A2 & The control panel & 4 \\
\hline B & B1 & The copper wire & 3 \\
\cline { 2 - 4 } & B2 & $\begin{array}{l}\text { Automatic feed delivery } \\
\text { system of blocks }\end{array}$ & 4 \\
\cline { 2 - 4 } & B3 & Wires cooling system the & 3 \\
\hline C & C1 & $\begin{array}{l}\text { The line at which the } \\
\text { movable block is }\end{array}$ & 2 \\
\cline { 2 - 4 } & C2 & Construction of machines & 2 \\
\cline { 2 - 4 } & C3 & Housing & 2 \\
\hline
\end{tabular}

Source: Own interpretation

From the data in Table 2. and Fig. 6 shows that any part did not reach 5. In contrast, $100 \%$ of the basic components from the group A are level 4 has been produced with assistance of modern technology. 
Subassemblies assist with Group B set at 3 include: wire Copperweld (B1) and wires cooling system (B3). The automatic feeding blocks was classified at level 4.

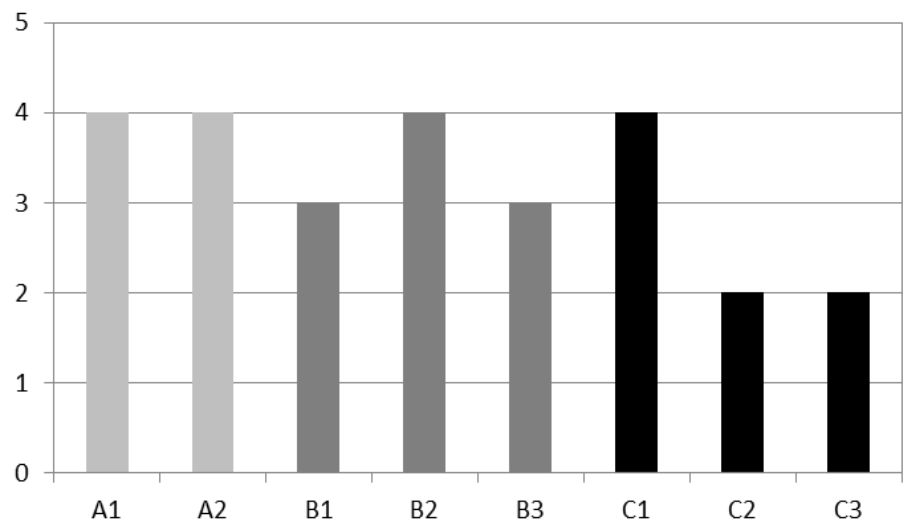

Fig. 9.6. The chart of technology level of parts the machine for forming blocks of polystyrene

Source: Own interpretation

The design of machine $(\mathrm{C} 2)$ and the housing $(\mathrm{C} 3)$ from the group $\mathrm{C}$ ancillary parts are at level 2, that are manufactured using technology known for many years. The line at which the block is moved (C1) was measured at 4 .

In Table 3 and Fig. 7 presents an assessment of modernity packaging machine feeder plates according to the $\mathrm{ABC}$ method of technology and Parker's five-point scale. 
Table 3. The technology level of parts the plates packaging machine with feeder

\begin{tabular}{|l|l|l|l|}
\hline $\begin{array}{l}\text { Group units of the } \\
\text { machine }\end{array}$ & No. & Sub-assembly machine & Technology level \\
\hline \multirow{4}{*}{ A } & A1 & The control system & 4 \\
\cline { 2 - 4 } & A2 & The control console & 4 \\
\cline { 2 - 4 } & A3 & Electric engine & 4 \\
\cline { 2 - 4 } & A4 & The welding head & 4 \\
\hline \multirow{2}{*}{ B } & B1 & Plate feeder & 3 \\
\cline { 2 - 4 } & B2 & $\begin{array}{l}\text { Temperature } \\
\text { System }\end{array}$ & 3 \\
\hline C & C1 & Construction of machines & 2 \\
\cline { 2 - 4 } & C2 & Housing & 2 \\
\hline
\end{tabular}

Source: Own interpretation

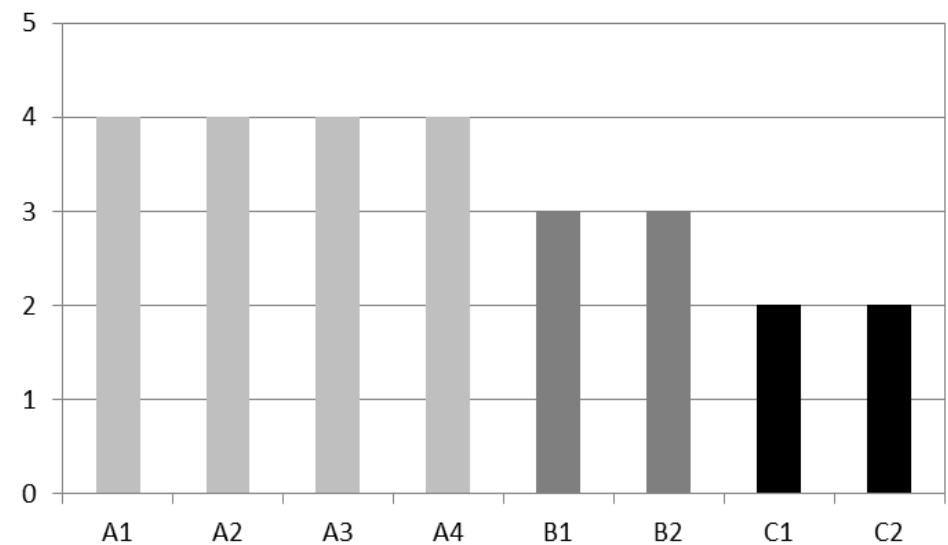

Fig. 5. The chart of technology level of parts the plates packaging machine with feeder

Source: Own interpretation

The data in Table 3 and Fig. 7 provide information that, in the case of the packaging machine feeder plates also were not applied the latest 
technologies unique to a particular company, because none of the components has not been evaluated at a level 5. However, all essential parts belonging to the group And, they are on level 4, which are manufactured using modern technology.

Feeder plates (B1), and a temperature control system (B2) from the group of components supporting been set at 3 , which means that they have been produced using the technology is requiring technical expertise.

Parts of ancillary from Group C, namely construction of the machine (C1) and housing (C2) qualified at level 2, and so to produce them changed for applied technology and known for years.

\section{Conclusion}

The research conducted is focused primarily on one type of Styrofoam - Styrofoam facade with dimensions 1000 × 500 × 20 do $500 \mathrm{~mm}$ and the thermal conduction coefficient $\lambda=0,042[\mathrm{~W} /(\mathrm{m} \cdot \mathrm{K})]$. In the analyzed work performed research for the machines that because of the strategic areas of production correspond to the greatest extent by the level of quality of the finished product. Based on the study in one of the national companies involved in the production of this type of polystyrene for construction it can be stated that factory technological equipment is at 3.4 in Parker's five-point scale. This assessment comes mostly quite low Rankings for machinery components from Group C. In contrast, looking at these machines through the prism of $\mathrm{ABC}$ analysis technology, components from group A were rated at level 4 in Parker's five-point scale, which proves that the company analyzed in their machines have the components of a good global level. Analyzing the capabilities and potential of the audited company can say that the current state of technological resources company and the quality of products manufactured and the low level of non-conforming products, there is no recommendation modernization of the equipment in order to increase the level of current technological resources. 


\section{Bibliography}

1. BoRKOWSKI S., 2004. Mierzenie poziomu jakości. Wydawnictwo Wyższej Szkoły Zarządzania i Marketingu. Sosnowiec.

2. BORKOWSKI S., 2005. Zarządzanie jakościa wyrobów i usług. Wydawnictwo Menedżerskie PTM. Warszawa.

3. Borkowski S., SelejdaK J., SAlamon S., 2006. Efektywność eksploatacji maszyn i urządzeń. Sekcja Wydawnictw Wydziału Zarządzania Politechniki Częstochowskiej. Częstochowa.

4. Borkowski S., UlewiCz R., SElejdaK J., 2005. Materiałoznawstwo dla ekonomistów. Wydawnictwa Naukowo-Techniczne. Warszawa.

5. Ciszewski A., RAdOMSKI T., SzUMER A., 1998. Materiałoznawstwo. Wydawnictwo Politechniki Warszawskiej. Warszawa.

6. Hyla I., 2000. Tworzywa sztuczne: własności, przetwórstwo, zastosowanie. Wydawnictwo Politechniki Śląskiej. Gliwice.

7. OsIECKA E., 2005. Materiaty budowlane, tworzywa sztuczne. Oficyna Wydawnicza Politechniki Warszawskiej. Warszawa.

8. OZIMINA D., MADEJ M., 2010. Tworzywa sztuczne i materialy kompozytowe. Wydawnictwo Politechniki Świętokrzyskiej. Kielce.

9. SELEJDAK J., BORKOWSKI S., 2006. Use of ABC method for assessment of modern milling machine applied for carrying roller production. ŻilinaSulov.

10. Sygut P., Krynke M., MielcZAReK M. 2012. Process Improvement in Industry of Building Materials. Chapter 5. s.56-65. W: Toyotarity. Improvement of Production/Service Processes. Monography. Editing and Scientific Elaboration Stanisław Borkowski, Piotr Sygut. Celje. 